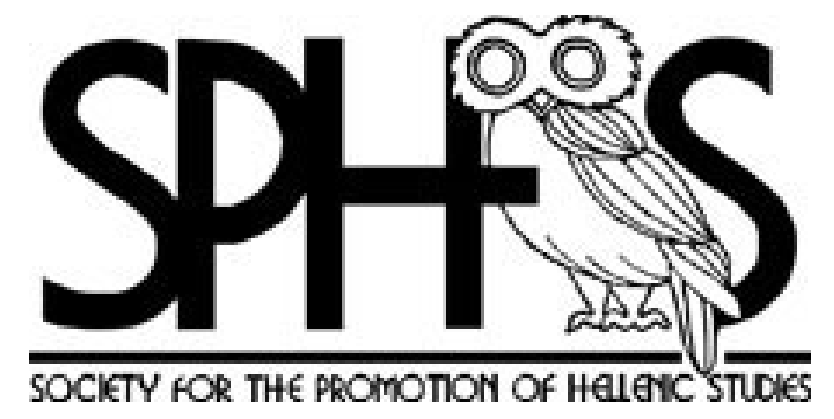

The Homeric House, in Relation to the Remains at Tiryns

Author(s): R. C. Jebb

Source: The Journal of Hellenic Studies, Vol. 7 (1886), pp. 170-188

Published by: The Society for the Promotion of Hellenic Studies

Stable URL: http://www.jstor.org/stable/623640

Accessed: $12 / 01 / 2015$ 22:30

Your use of the JSTOR archive indicates your acceptance of the Terms \& Conditions of Use, available at

http://www.jstor.org/page/info/about/policies/terms.jsp

JSTOR is a not-for-profit service that helps scholars, researchers, and students discover, use, and build upon a wide range of content in a trusted digital archive. We use information technology and tools to increase productivity and facilitate new forms of scholarship. For more information about JSTOR, please contact support@jstor.org.

The Society for the Promotion of Hellenic Studies is collaborating with JSTOR to digitize, preserve and extend access to The Journal of Hellenic Studies. 


\section{THE HOMERIC HOUSE, IN RELATION TO THE REMAINS AT TIRYNS.}

EverY discussion relating to Tiryns may fitly commence with a tribute to the energy and enthusiasm which, there as elsewhere, have characterised the excavations of Dr. Schliemann ; a tribute which has at all times been ungrudgingly rendered by his critics, even when they have been least able to accept the theories which have been founded on those results by the distinguished excavator. It will not be the purpose of the present paper to discuss the questions which have been ruised concerning the origin and age of the remains at Tiryns; whether, as Dr. Dörpfeld holds, they represent a prehistoric palace, built by Phoenicians about 1100 B.c.; or, as others believe after seeing them, belong to buildings of post-classical date and of rude construction, in which partial use was made of archaic or classical material found on the spot. The question with which alone this paper deals is the following. Given the plan of the house at Tiryns, as Dr. Dörpfeld traces it, can this plan be reconciled with that of the typical Homeric house, as indicated in the Homeric poems? By 'reconciled' is not meant, harmonised in every detail, but brought into an intelligible agreement as regards features essential to the Homeric story. The position maintained in Dr. Schliemann's work is that, with reasonable allowance for variations between one house and another of the same period, such a general reconciliation is possible. This is a very important issue, not only for Homeric archaeology, but for all study of Homer. ${ }^{1}$

1 Among recent writings on the Homeric House, the following may be mentioned: (1) Winckler, Dic Wohnhäuser der Hellenen, Berlin, 1868;
(2) Papers by Mr. Watkiss Lloyd in the Builder of June 4th and 25th, 1870 ; and in the Architect of August 4th and 11th, 1877; (3) A note by 
Assuming the accuracy of the ground-plan delineated by Dr. Dörpfeld, we find in the house at Tiryns certain general features common to the Homeric house. The Homeric $\pi \rho o$ ov $\nu \rho \nu$, or front entrance to the court, is identified with a propylaeum; a form of gateway which archaeologists have been startled to find associated with a prehistoric building in Greece, where its earliest appearance had not hitherto been carried above the fifth century B.c. We find also the courtyard ( $\left.a v^{\lambda} \lambda \eta^{\prime}\right)$, with a colonnade on all four sides, - that on the side opposite to the front entrance being

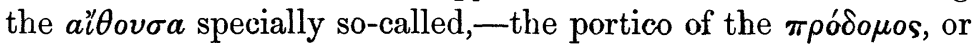
fore-hall. Immediately within this is the great hall of the men,

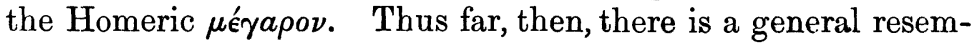
blance. But we now come to a difference of the most striking and essential kind. At Tiryns the men's hall has no outlet except the door by which it is entered from the fore-hall. The women's apartments are identified with a second and smaller hall, completely isolated from the other. This smaller hall has

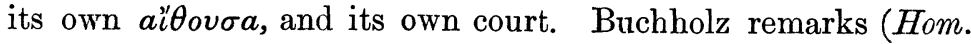
Realien, ii. 93): 'Everywhere in Homer an $a \dot{\nu} \lambda \eta^{\prime}$ is mentioned, never $a \dot{v} \lambda a i$, so that the view of those who assert that there were two, may be regarded as finally disposed of.' Dr. Dörpfeld replies (Tiryns, 237): 'This sentence is directly refuted by the palace at Tiryns. There may indeed have been palaces in Homer's time which had only one $a \dot{u} \lambda \eta^{\prime}$; but we now know for certain that some there were which contained two.' From the men's hall to the women's apartments the only modes of access were by very circuitous and intricate routes. ${ }^{1}$ (See Plan I.)

Mr. A. Lang on Od. 22. 2, in Butcher and Lang's translation; (4) J. Protodikos, De Aedibus Homericis, Leipsic, 1877. He has consulted, besides Winckler's work, writings by A. Hirt, H. Rumpf, Eggers, J. B. Friedreish, J. H. Krause, Emil Wörner, L. Gerlach; (5) A An article by Prof. P. Gardner in the Journal of Hellenic Studies, iii. 264 ; (6) E. Buchholz, Homerische Realien, Leipsic, 1871-3. Helbig, (Das Homerische Epos aus den Denkmälern erläutert) I. viii. pp. 74-88, deals with the materials and decorations of the house, rather than with its plan.
1 They are thus described by Dr. Dörpfeld (Tiryns, p. 236) :-' In the north-west part of the palace lies a small court, with colonnades and adjoining rooms, which has no direct connection with the main court; it is the court of the women's dwelling. You must pass many doors and corridors to reach this inner part of the palace. There appear to have been three ways of reaching it. First, from the back-hall of the great Propylaeum, through the long passage XXXVI., to the colonnade XXXI.; and from this, through the outer court $\mathrm{XXX}$., to the east colonnade of the 
In the Homeric house, on the contrary, as the Homeric poems indicate it, the women's apartments are immediately behind the men's hall, and directly communicate with it by

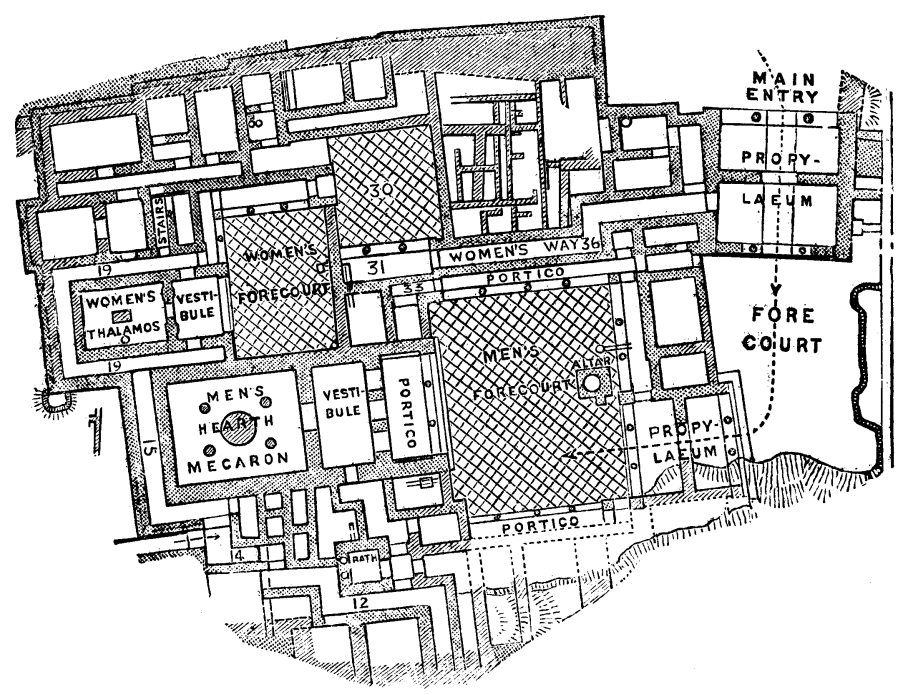

Plan I. - The House at Tirins.

a door, as shown in plan II. ${ }^{1}$ The contention in Dr. Schliemann's book is that the Homeric data do not require such an arrangement, but are compatible with the arrangement

women's court. Secondly, you could go from the great court or from the megaron, past the bath-room, into corridor XII., and then through passages XIV., XV., and XIX., to reach the vestibule of the women's apartments. A third way probably went from the east colonnade of the great court, through room XXXIII., into the colonnade XXXI., and then along the first way into the court of the women's apartments. All these three approaches are stopped in several places by doors, and the women's apartment was therefure quite separated from the great hall of the men's court.'

The above three routes can easily be traced on our Plan I. (copied from part of a reduction of Dörpfeld's plan in the Quarterly Review for Jan. 1886), by means of the Arabic numerals which I have placed to represent Dörpfeld's Roman numerals: (1) for the first route, $-36,31,30:$ (2) for the second, $12,14,15,19:$ (3) for the third, 33 , 31,30 .

1 This general feature is common to all plans of the Homeric house hitherto given. I have taken the plan of $J$. Protodikos as a basis. 
found at Tiryns. I propose, therefore, to do what (so far as I know) has not been done before,-riz., to present in a connected form the evidence of the Odysscy on this question. As the house of Odysseus is that which will almost exclu-

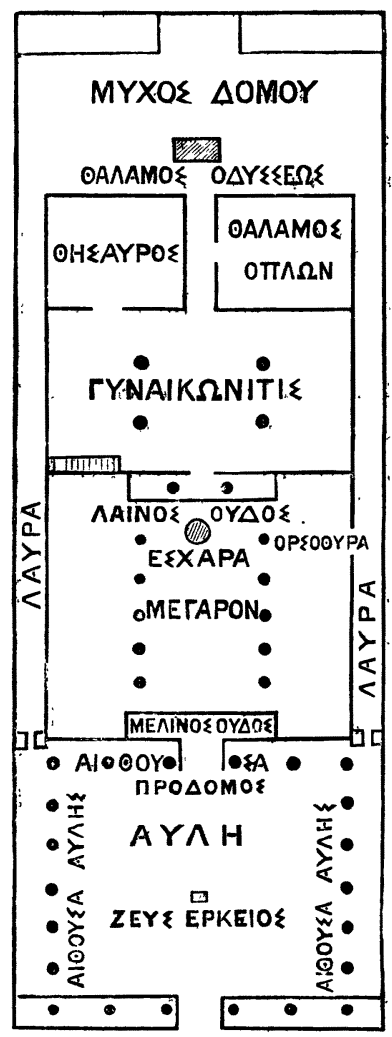

Pran II.-The Honeric House of the Odyssey.

sively engage our attention, it is right to observe that, on this question, little or no additional light can be gained from the other Homeric houses, though they afford confirmatory evidence on some points. It will be practically convenient to begin with a series of passages which are independent of any 
obscure or doubtful points in the $\mu \nu \eta \sigma \tau \eta \rho o \phi o \nu i a$, and then to consider that episode separately.

I. Passages showing that the women's apartments were behind the megaron, or great hall of the men, and directly communicated with it by a door.

1. In book xvii. Odysseus comes to his house in the guise of an aged beggar. Telemachus, to whom alone the secret is known, is in the great hall with the suitors. Odysseus, with the humility proper to his supposed quality, sits down 'on the threshold of ash, within the doors' (17. 339):

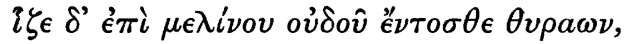

i.e. at the lower end of the hall, on the threshold of the doorway leading into it from the prodomos. The suitors who, with their retinue, numbered about a hundred and twenty, were feasting at a series of small tables, which may be imagined as arranged in two rows from end to end of the hall, leaving in the middle a free space in which the twelve axes were afterwards set up. Telemachus sends food to Odysseus, with a message that he should advance into the hall, and beg alms from table to table among the suitors. Odysseus does so, and, while he is thus engaged, one of the suitors, Antinous, strikes him. Odysseus then returns to his place on the ashen threshold. Meanwhile Penelope is sitting among her handmaids in the women's apartments (17. 505). She hears-doub,tless through one of the women-servants - of the blow dealt by Antinous to the humble stranger; and she sends to the hall for Eumaeus. When he comes, she desires him to go and bring the mendicant into her presence. He delivers her message to Odysseus, who is still seated on the ashen threshold. Odysseus replies that he would gladly go to Penelope; 'but,' he adds, 'I somewhat fear the throng of the forward wooers. . . . . . For even now, as I was going through the hall, when yon man struck me, and pained me sore,- - though I had done no wrong,-neither Telemachus nor anyone else came to my aid.' ${ }^{1}$ That is, he declines to go to

\footnotetext{
1 Od. 17. 561.

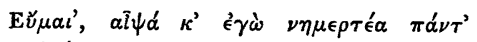

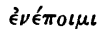

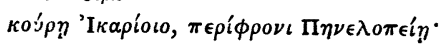

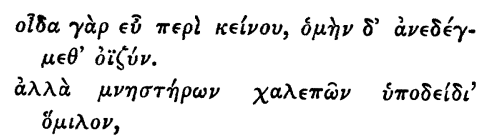


Penelope, because, in order to reach her apartments, he would have to pass up the hall, among the suitors, one of whom had already insulted him. ${ }^{1}$

2. The supposed mendicant is then accommodated for the night with a rough 'shake-down' in the prodomos-the fore-hall or vestibule of the megaron. As he lies awake there, he observes some of the handmaids pass forth from the men's hall (20.6):-

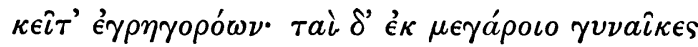

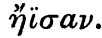

But, after escorting Penelope to the interview with the stranger in the hall, they had returned to the women's apartments (19.60). Thus again it appears that the direct way from the women's apartments to the court lay through the men's hall.

3. The next day, while the suitors are revelling in the hall, and taunting Telemachus, Penelope is sitting, as before, in the women's apartments. She is not in her own room on the upper storey, to which she presently ascends (21. 5), but on the groundfloor, level with the hall. She places her chair 'over against' the hall ( $\left.\kappa a \tau^{\prime}{ }^{\prime} \nu \tau \tau \eta \sigma \tau \iota \nu, 20.387\right)$, i.e. close to the wall dividing the hall from the women's apartments; and thus 'she heard the words of each one of the men in the hall' (20.389). Similarly in 17.541, being in the women's apartments, she heard Telemachus sneeze in the hall. Such incidents would be impossible in a house of the type supposed at Tiryns.

4. In preparation for the slaying of the suitors, Odysseus and his son decide to remove the arms from the hall, and to carry them to a room in the inner part of the house. That such was the position of the armoury is made certain by the phrases used

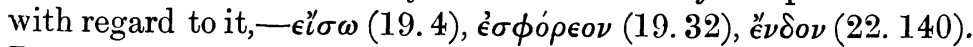
But, before doing this, Telemachus, in the hall ' called forth' the

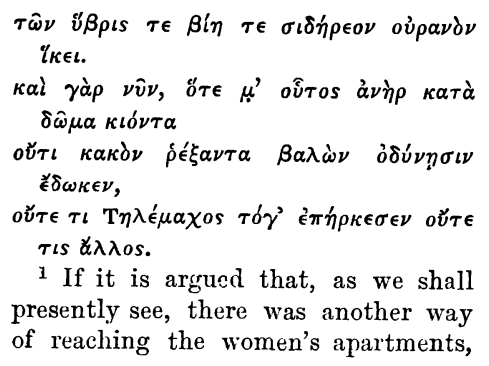

1 If it is argued that, as we shall presently see, there was another way of reaching the women's apartments,

-viz., by an outside passage, -it is enough to reply that the supposed stranger need not have been expected to know this; and that Eumaeus might well refrain from suggesting it, - - either as divining the stranger's reluctance (Odysseus was waiting till he could see Penelope alone), or as thinking such a back-way an unsuitable mode of bringing the new-comer to the mistress of the hcuse. 
nurse Eurycleia (19. 15), and said to her: 'Shut up the women in their chambers, till I shall have laid by in the armoury the goodly weapons of my father.' Thereupon 'she closed the doors of the chambers' (19.30), and the removal of the arms was effected. Whence was Eurycleia 'called forth' into the hall? Evidently from the women's apartments immediately behind it, as in the similar case at 21. 378. The doors which she closed were those leading from the women's apartments into the hall. The arms were then taken from the hall to the armoury by a side-passage (to be noticed presently), which ran along the wall on the outside.

II. The episode of the vengeance in book xxii. entirely confirms the conclusion drawn from the passages noticed above. The scheme is that the suitors are to be shut up in the hall, and then shot down by Odysseus, his son, and the two faithful servants (Eumaeus and Philoetius), who command the access to the armoury. The door at the upper end of the hall, leading into the women's apartments, is fastened, from within them, by Eurycleia, before the conflict begins (21.387), and unfastened by her when it is over (22. 399). The door at the lower end of the hall is closed,-for javelins strike it (22. 257), - but it is not fastened; that was unnecessary, since it was commanded by Odysseus, who stood on the threshold in front of it. We observe that, when the slaughter is over, Phemius and Medon pass freely out by this duor from the hall into the court (22.378), although nothing has been said about unfastening it; whereas, in the case of the other door, at the upper end of the hall, the act of unfastening receives express mention (22. 399). The front door of the court ( $\theta \dot{v} \rho a \iota \quad a \dot{\nu} \lambda \hat{\eta} s)$ has been fastened from within by Philoetius, who, after doing so, passed back into the hall (21. 389).

Thus the plan of action-perfectly clear and simple in outline - not only allows, but requires, that the women's apartments should be behind the hall, and should communicate with it by a door. This is the main point with which we are concerned, and this is certain. Some minor details are more doubtful. It is interesting to consider these, and, if we can, to form a distinct conception of the episode as a whole.

1. The first question which might be raised is, 'From which end of the hall did Odysseus shoot the suitors?' I have already 
intimated my belief that it was from the lower end. But the evidence for the other view must be attentively examined.

The threshold on which Odysseus first sat is called, as we have seen, the threshold of ash ( $\mu$ é $\lambda \iota \nu o s)$, and was at the lower end of the hall (17.339). Next day Telemachus makes him sit down

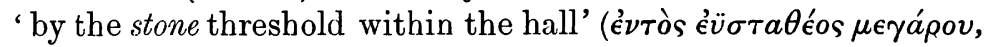

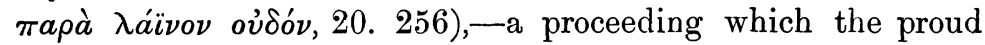
suitors resented, though Telemachus had provided his humble guest only with ' a mean settle and a little table.' The stone threshold-if there was only one stone threshold-was certainly at the upper end of the hall. In 23. 88 Penelope crosses 'the stone threshold' in passing from the women's apartments to the hall. Two other circumstances confirm this inference. (i) When the suitors try the bow of Odysseus, they come to the threshold for that purpose, and the first to come is Leindes, who always sat $\mu v \chi o i \tau a \tau o s,-i n$ the innermost part of the hall (21.146). $\mathrm{He}$ was the $\theta v o \sigma \kappa o$ os of the suitors, and had that place, not

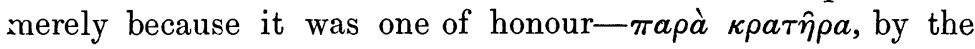
mixing-bowl (21. 145) - but also, no doubt, in order that he might be near the $\dot{\epsilon} \sigma \chi a \dot{\alpha} a$. Thus, the stone threshold being at the upper end, Leiodes would be the nearest to it of the suitors, and would naturally be the first to try the bow. (ii) In 21.359 Eumaeus takes up the bow to carry it to Odysseus, as had been arranged between them. The suitors raise an outcry, and Eumaeus sets it down again, but is commanded by Telemachus to advance with it. 'And the swine-herd, carrying the bow through the hall, came and stood by Odysseus, and put it into his hands ; and he called forth Eurycleia and spake to her,'-bidding her close the women's apartments (21. 379). Thus, when standing by Odysseus, Eumaeus is near the door of the women's apartments; for all his movernents have been closely described up to the moment at which he reaches the side of Odysseus. In the course of book xxi. Odysseus rises from his seat near the stone threshold, and goes out of the hall with Eumaeus and Philoetius (21. 190); but the poet is careful to say that he returned to the same seat (243). From that seat he sends the arrow through the holes in the axes (21.420). Immediately afterwards the slaughter of the suitors begins. Its beginning is marked by the words, 'he sprang on to the great threshold' (22. 2). If the 'great' threshold is the same as the 'stone' H.S.--VOL. VII. 
threshold, then Odysseus shot the suitors from the upper end of the hall.

Mr. A. Lang is (or was) disposed to adopt this view, observing in his note on 22. 2 that it is not Homeric to leave unmentioned so important a movement as one from the upper to the lower end of the hall. On the other hand, Mr. Watkiss Lloyd, in the Architect of Aug. 11, 1877, assumes that Odysseus passed from the upper to the lower end of the hall, though the poet has not told us so. I concur with Mr. Lang's criticism, but with Mr. Lloyd's conclusion. It seems to me that the difficulty as to the poet's silence is greatly lessened, if it is not altogether removed, by the words of Odysseus just after he has sent the arrow through the axes, and just before he springs on the threshold. The supposed mendicant turns to Telemachus, and says :'Telemachus, thy guest that sits in the halls does thee no shame. In nowise did I miss my mark, nor was I wearied with long bending of the bow. Still is my might steadfast,- - not as the wooers say scornfully to slight me. But now it is time that supper too be got ready for the Achaeans, while it is yet light, and thereafter other sport be made with the dance and the lyre, for these are the crown of the feast.' 1

It is obvious that these words would be perfectly suitable to the moment, if, while he pronounced them, the stranger should rise from his seat and proceed down the hall, as if about to retire from it. He would thus say, in effect,- ' Sir, I have now justified your courtesy to a humble guest; and, having done so, I leave these lords to their festivities.' So, while I agree that it would be un-Homeric to leave the movement of Odysseus unnoticed, I think that Homer, without mentioning, has indicated it, and that, too, in a highly dramatic manner. There is still a possible objection to be met. If the stone threshold was not that from which Odysseus was to shoot the suitors, what was the 'crafty design' with which Telemachus had seated him near

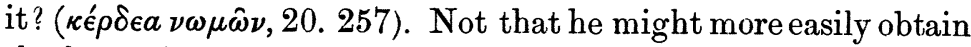
the bow; for the trial with the bow occurs to Penelope's mind only at the beginning of book xxi.; and the scheme originally concerted between father and son was that, in removing the

121.424 , f. In giving Butcher and Lang's version, I substitute 'other sport be made' for 'we make other sport.' In the original it is simply

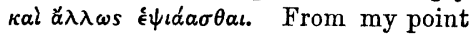
of view the difference is significant. 
other arms from the hall, Telemachus should leave weapons for their own use (16. 295). The 'crafty design' must, then, have been simply that Odysseus might be better able to see that the door of the women's apartments was closed, and might be near his son when the moment should arrive for giving the signal (21. 431).

If, on the other hand, the 'great' threshold from which Odysseus shot the suitors was at the upper end of the hall, several passages become unintelligible.

(1) In 22.75, during the fight, Eurymachus (one of the suitors) says, 'Let us all have at him with one accord, if haply we may drive him from the threshold and the doorway, and then go through the city.' 1

(2) In 22.250 Odysseus and his three comrades are described

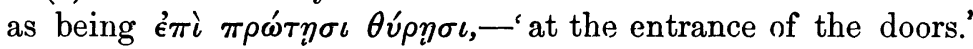
This phrase would be wholly inappropriate to the door at the upper end of the hall.

(3) In 22. 270 the suitors fall back before Odysseus $\mu \epsilon \gamma a ́ p o \iota o$ $\mu v \chi o ́ v \delta \epsilon$,- to the innermost part of the hall. The word $\mu v \chi^{\prime}$ s is not one which could be applied indifferently to either end of the hall. It means the end farthest from the entrance,- - the 'ben.' Compare 7. 87 and 96 (with reference to the house

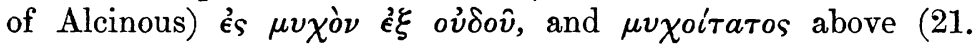
146).

Unless, then, we conclude that Odysseus passed from the upper to the lower end between trying the bow and beginning the onslaught, we have to suppose a $\lambda$ áivos ovjoós at both ends.

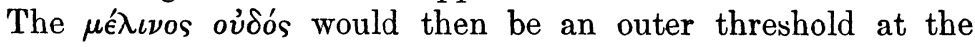
lower end. But this is most improbable.

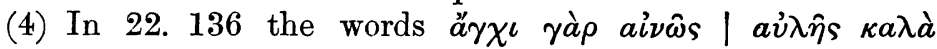
$\theta$ v́ $\varepsilon \tau \rho a$ furnish another argument on the same side, but this will be best taken presently, in connection with the second question of detail raised by book xxii. It is the following.

2. How were arms introduced into the hall after the fight had begun?

A.t the end of book xxi. the situation is as follows. Odysseus has his bow and arrows, but is otherwise unarmed. Telemachus

122.75.

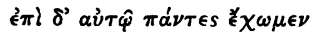

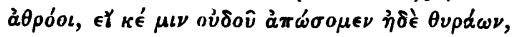

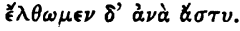


has a sword and a spear. The last two lines of book xxi. are traditionally read thus :-

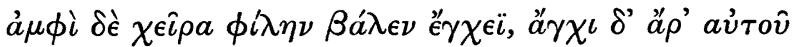

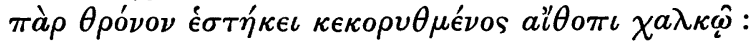

Telemachus 'took the spear in his grasp, and stood by his high seat at his father's side, armed with the gleaming bronze.' There are two objections to this. (i.) As appears from 22. 103 and 113, .Telemachus had no defensive armour, such as $\kappa \epsilon \kappa o \rho v \theta \mu$ '́ $\nu$ os denotes, until he brought it from the armoury: then 'he girded the gear of bronze about his own body first' (22. 113). (ii.) He was not yet 'at his father's side.' It is only at 22. 99,- -after killing one of his father's assailants with

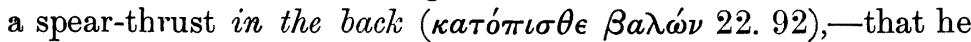
rushes forward and joins his father on the threshold. In 21.434

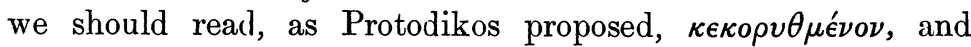
translate:- 'he took the spear in his grasp; near him it stood

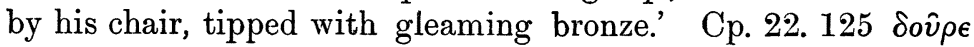
$\delta v^{\prime} \omega \kappa \epsilon \kappa o \rho v \theta \mu \epsilon \in v a ~ \chi a \lambda \kappa \hat{\omega}$. Telemachus was sitting at one of the small tables at the upper end of the hall. His chair was probably set,-like that of Demodocus in the house of Alcinous, -near a pillar, against which his spear leaned. Having come to his father's side on the threshold, he proposes to bring arms for both of them, and for the two servants. Odysseus bids him run and bring them at once (oî $\sigma \epsilon \theta \dot{\epsilon} \omega \nu, 22.106)$. He at once goes to the armoury in the inner part of the house $\left(\beta \hat{\eta} \delta^{\prime} \iota^{\prime} \mu \epsilon \nu a \iota\right.$ $\theta a$ ' $\lambda a \mu o ́ \nu \delta ', 109$ ), and returns 'very quickly' (112) with four helmets, four shields, and eight spears. Observe in passing how rapid and easy is the way of access to the armoury which all this implies. But what was that way? One way alone was open to him, if, as we have shown, he was at the lower end of the hall. It was the same way by which, before the conflict, the arms had been removed from the hall, after the door at its upper end was closed,-viz., a passage running along the wall of the hall on the outside, and so leading back to the inner part of the house.

The suitors are now hard-pressed, and a similar manoeuvre is undertaken in their interest. At 22. 126 we read ${ }^{1}$ :- ' Now

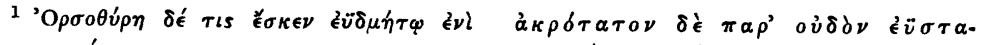

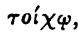

$\theta \in \operatorname{os} \mu \epsilon \gamma a ́ \rho \circ$ o
} 


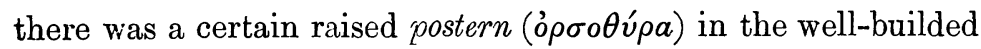
wall; and by the uttermost threshold of the stablished hall there was a way into a passage (óoòs és $\lambda a v ́ \rho \eta \nu$ ), closed by well-fitted folding-doors ( $\sigma a \nu i \delta \epsilon s)$. And Odysseus bade the goodly swineherd stand near thereto and watch the way, for there was but one approach.'

All interpreters, so far as I know, have assumed that the postern (ópotvía) was identical with the 'way into a passage' (óòs $\epsilon i s ~ \lambda a u ́ p \eta \nu$ ), closed by folding-doors. Consequently they

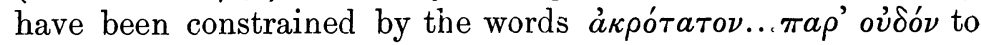

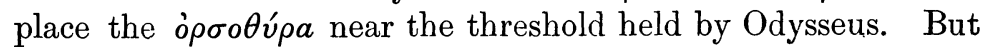
an insuperable difficulty then arises. On this view, Eumaeus is standing near the ópootúpa, guarding it. And yet Agelaus, one of the suitors, proposes to Melanthius (the goat-herd, in

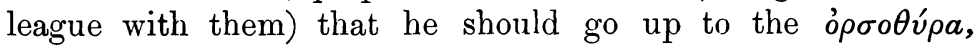
- guarded by Eumaeus, and close to the deadly threshold,and so sally forth to raise the town! Obviously the ó $\rho \circ \theta \dot{v} \rho a$ was nearer to the upper than to the lower end of the hall, and was under the command of the suitors. Another proof of this oecurs at 22. 333, where Phemius,- - when the surviving suitors are already cowering at the upper end,-proposes to slip out by the o $\rho \sigma o \theta \dot{v} \rho a$ into the court,-Eumaeus having now left his post of watch near the threshold, in order to join in a charge on the suitors (22. 307). The óoòs és $\lambda a v$ óp $\nu$ was, I think, distinct from the ópootv́pa. It was a second way of reaching the $\lambda a v \rho a$ from the hall. It was opposite the end of the threshold on which Odysseus stood, and could be closed by folding-doors ( $\sigma a \nu i \delta \epsilon s)$. These folding-doors were now open, and Eumaeus was posted near them, ready to intercept any one attempting to pass from the hall, by the $\lambda a v$ pa, into the court. There was 'only one way of approach,' viz., by the $\lambda a v$ pa itself, which the

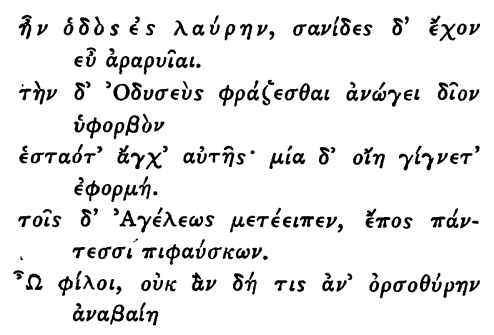

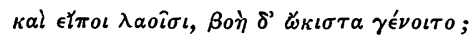

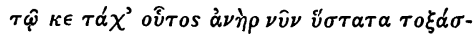
бalto.

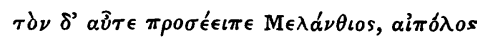
aì $\hat{\omega} \nu$.

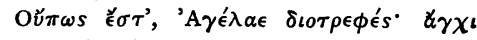
$\gamma \grave{\alpha} \rho$ aiv $\hat{\omega} s$

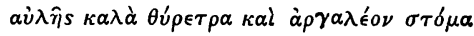
$\lambda a v ́ \rho \eta s$. 
enemy could enter by the óorotv́ $\rho$ at the upper end. There was an evident utility in such a second entrance to the $\lambda$ aú $\rho a$ from the lower end of the hall. By its proximity to the mouth of the $\lambda a v$ pa, opening on the court, it enabled occupants of the hall to command that entrance. The special convenience of the $\dot{o} \rho \sigma o \theta \dot{v} \rho a$, on the other hand, would be rather for communication with the back part of the house, and more particularly for service. When it is proposed to Melanthius that he should

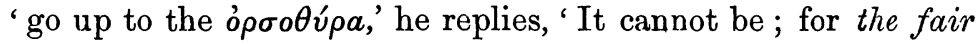
doors of the court are terribly near, and strait is the mouth of the passage' (22. $136 \mathrm{f}$.). That is, 'Eumaeus down yonder could hold the narrow passage against me, and his allies are close by, at the door leading from the hall to the court.'

But Melanthius has another resource. 'Come,' he says, 'let me bring you armour from the thalamos,-for methinks 'tis within, and nowhere else, that Odysseus and his son laid by the arms.' So saying, 'he went up by the $\dot{\rho} \omega \hat{y e s}$ of the hall,' ${ }^{\prime}$ and quickly returned with a supply of arms, - twelve shields, twelve helmets, and twelve spears.

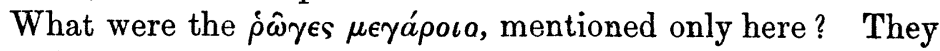
have been explained as a clerestory, by which Melanthius gained the roof of the hall. Dr. Dörpfeld supposes that the hall at Tiryns had a clerestory over its four central pillars; though the late Mr. James Fergusson, who assumed a basilican mode of lighting for the Parthenon, thought it improbable in the case of Tiryns. Others, again, have taken the $\dot{\rho} \hat{\omega} \gamma \epsilon \varsigma$ to be windows in the side-walls; or stairs leading to the roof ; or shelves, forming part of sleeping-galleries, along the sides of the walls. The feature common to almost all explanations has been to understand àvé $\beta a \iota \nu \epsilon$ as meaning that Melanthius climbed up something. But he quickly returns with a great load of armour. And neither his exit nor his return is noticed by Odysseus. Both these facts seem incompatible with the idea of climbing, unless the $\dot{\rho} \hat{\omega} y \epsilon s$ are supposed to be regular stairs outside of the hall. On the other hand a $a \epsilon^{\prime} \beta a \iota \nu \epsilon$ ought certainly to mean 'went up,' not merely, 'went back.' The Homeric use of this verb always implies literal ascent,- -as in going on board ship; though the

\footnotetext{
122.142

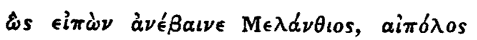

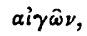

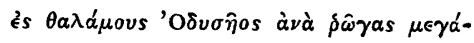
poเo.
} 
Homeric use of $\dot{a} \nu \dot{a}$ with the acc. is larger (e.g., Od. 12. $333 \dot{a} \nu \grave{a}$ $\nu \eta \hat{\sigma} \sigma o \nu$ a' $\pi \epsilon \tau \tau \iota \chi o \nu$, i.e. 'up' from the coast). And this condition is satisfied, if we suppose that Melanthius, in order to reach the

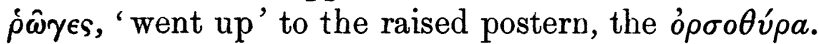

It is to the Modern Greek language, and to scholars writing in it, that we are indebted for preserving the true interpretation of $\dot{\rho} \hat{\omega} \gamma \in s$, as I, at least, cannot hesitate to think it. The Homeric

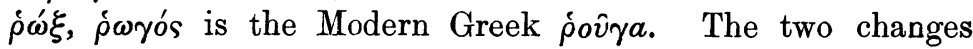
which have taken place are both normal. (i.) The ancient $\omega$

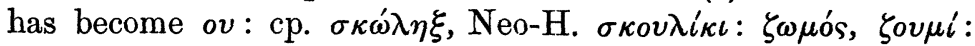

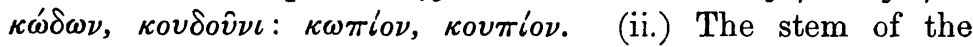
ancient noun of the third declension has been used to form a

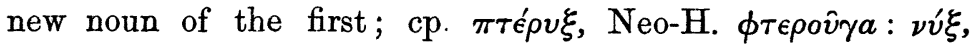

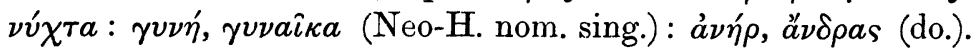
In his Dictionary of Modern Greek (1835), Skarlatos, of Constantinople, giving fov̂ya as 'a narrow way or passage,' compares the Homeric $\dot{\rho} \hat{\omega} \gamma \epsilon \varsigma$. In a Greek version of the Homeric Lexicon of Crusius (Athens, 1874) J. Pantazides says on $\dot{\rho} \omega \gamma \epsilon s:$ "The most probable interpretation is that of Eustathius, "passage," "narrow way," ' and refers to the modern povya. And the same interpretation is adopted by J.Protodikos (1877). ${ }^{1}$ I am indebted to Professor M. Constantinides for a valuable note on this subject. Speaking as a native of Northwestern Asia Minor, he observes that $\dot{\rho} o \hat{v}$ a $a$ is thoroughly familiar, in the sense of 'lane,' to the Greeks of Asia Minor, though it is rare among Greeks of Europe, who employ instead a Turkish word, $\sigma \omega \kappa a ́ \kappa \iota$. One illustration of the modern use which he has given me is so apposite that it must be quoted. It occurs in a popular song from the region of Cyzicus. A young princess is gathering flowers and weaving them into chaplets, like Persephone of old, when she and her maidens are surprised by a monster, who, singling out the princess, chases her:-

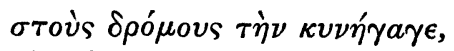
$\mu \grave{s} \tau \grave{\eta} \nu a \dot{v} \lambda \grave{\eta} \tau \grave{\eta} \nu \delta \iota \dot{\omega} \chi \nu \epsilon \iota$,

1 Another derivation has been suggested for povya,-viz., the Low Latin ruga ('furrow,' then 'path') whence O. It. ruga and Fr. mue (see Brachet s.v.). But the Greek use of $\dot{p}^{\circ} \hat{\gamma} \gamma \alpha$ goes too far back to make this explanation probable. And the way in which the $\hat{\phi} \hat{\omega} \gamma \epsilon s$ are mentioned (Od. 22. 143) proves that the word was in familiar use. 


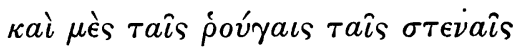

$\tau o \hat{v} \pi a \lambda a \tau \iota$ v $\tau \grave{\eta} \nu \phi \theta a ́ \nu \epsilon \iota$.

' he hunts her to the streets, he pursues her into the court, and in the narrow passages of the palace he overtakes her.'

The $\dot{\rho} \hat{\omega} \gamma \epsilon s \mu \epsilon \gamma a ́ \rho \circ o$ would, then, be narrow passages leading from the outside of the hall to the inner part of the house. We shall find that this perfectly agrees with the whole tenor of the passage from 22. 126 to 179 . Such $\dot{\rho} \hat{\omega} \gamma \epsilon \varsigma$ would be especially used for service, and it is natural that a servant of the house should know them. Agelaus had wished Melanthius to go up to the ó $\rho \circ \theta v$ v́ $a$,- which Melanthius could safely do,-and then to pass into the court,- - which he could not do without being intercepted by Eumaeus. Melanthius, therefore, 'went up' to the o $\rho \sigma o \theta v$ va, but, when inside it, turned in the opposite direction from that leading to the court,-along the passages ( $\dot{\rho} \hat{\omega} \gamma \epsilon \varsigma)$ leading to the back of the house. Odysseus and his men at the other end of the hall, busy with the conflict, do not notice the exit of Melanthius. We need not imagine the ópootúpa as raised high above the floor; and Melanthius, among the throng of suitors, could easily slip through it unnoticed. When he has returned to the hall, and the suitors are seen to have obtained armour, Odysseus suspects that it has been brought either by Melanthius or by the women (22. 151). At this moment, Odysseus, Telemachus, and Eumaeus are standing close together at the lower end of the hall,- - the two former on the threshold, and Eumaeus near the end of it, at the open folding-doors leading from the hall into the $\lambda a v$ pa (cp. 22. 163). Eumaeus, warned by Odysseus, now keeps his eyes on the o $\rho \sigma o \theta v \rho a$ at the upper end. When Melanthius slips out by it for the second time, Eumaeus espies him (22. 162). Then Eumaeus and Philoetius, passing out by the folding-doors into the $\lambda a v$ í $a$, follow Melanthius to the armoury at the back of the house, and catch him in the act of plundering it (22. 176). It may be asked,- Why did not Odysseus anticipate this manoeuvre of Melanthius, seeing that the suitors had the use of the o $\rho \sigma o \theta v ́ p a$ ?' The answer is given by the words of Telemachus (22. $155 \mathrm{f}$.), who takes the blame to himself, because he had left the door of the armoury ajar. Odysseus and Telemachus relied, then, on means of fastening the door of the armoury from 
the outside. Probably they had a $\kappa \lambda \epsilon i$ 's for it, as Penelope

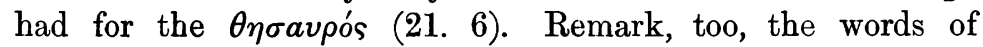
Telemachus: 'I left the door open, and there has been one of them but too quick to spy it' (22. 156). That is, ne suspects that one of the women, coming round by the $\dot{\rho} \hat{\omega} y \in s$ to the opootúpa, had reported his oversight to the enemy. 1

3. The sequel of the contest.-When the slaying of the suitors has been accomplished, Telemachus is ordered by his father to ' call forth' Eurycleia. He does so by shaking or striking a door, while he calls to her through it (22. 394), -

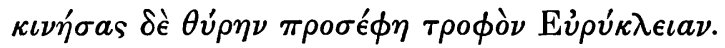

Then she opened the door,- the same which she had closed at 21. 387, - the door between the women's apartments and the hall. She enters the hall; Odysseus questions her concerning the conduct of the handmaids; and she receives his command to bring them forth from the women's apartments. Then 'she went through the hall to tell the women' (22.433). Odysseus next instructs Telemachus that they are to be 'led out of the hall ' into the court (441).

Thus the story of the Odyssey from book xvii. onwards presents itself as a clear and intelligible whole. In the view of it which I have endeavoured to present, there may be details on which opinions will be divided; but such details do not affect the main conclusion which it is my purpose to establish. The whole tenor of the narrative pre-supposes two essential conditions for the Homeric house :-

(1) The women's part of the house was immediately behind the men's hall, directly communicating with it by a door.

(2) There was a second way of going from the men's hall to. the back part of the house, by a passage outside of the hall;

\footnotetext{
1 Protodikos thinks, as I do, that

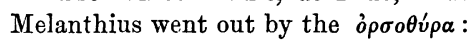

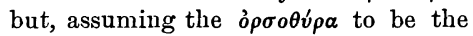
only way from the hall into the $\lambda a u^{\prime} \rho \alpha$, he has to suppose that the door which Eumaeus was set to watch was that leading from the mouth of the $\lambda \alpha u$ ú into the court. This places Eumaeus outside of the hall. But he was

H.S.-VOL. VII.
} inside it, close to Odysseus, to whom he speaks when he sees Melanthius slip out (22. 163). Further, he has

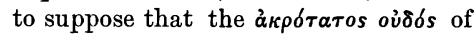
22. 127 is the edge of the threshold of the ópootípa on the side towards the $\lambda \alpha v^{\prime} \rho a$, and that it is called the ' threshold of the hall' merely because the o $\rho \sigma o \theta v o$ s led out of the hall. 
and this second way, though, of course, less direct than the other, was still easy and rapid,-as book xxii. abundantly proves.

With these two general conditions, we contrast two general conditions of the house at Tiryns :-

(1) The primary isolation of the women's apartments from the men's hall.

(2) The extremely circuitous and tortuous character of the only routes by which it was possible to pass from one to the other. For these, the reader may be referred to Dr. Dörpfeld's own description, quoted above (p. 171, note).

At p. $2 \div 7$ of Tiryns Dr. Dörpfeld argues that the arrangement at Tiryns can be reconciled with the Homeric data. $\mathrm{He}$ notices five passages only. The first four of these are only the oft-repeated verse in which Penelope, entering the hall from the women's apartments, is said to stand by the door-post of the hall $(1.333 ; 16.415 ; 18.209 ; 21.64)$ :-

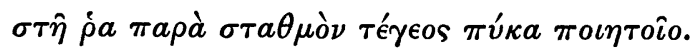

On this Dr. Dörpfeld merely says that the door at the lower end of the hall is intended. The fifth passage (21. 236) is that in which, before the slaying, Eurycleia is ordered to shut the doors of the women's apartments. On this Dr. Dörpfeld remarks that there is nothing to show that these doors opened on the hall; and that the object of closing them was ' not to keep the suitors from escaping, but to keep the women undisturbed within.' Those who have followed the evidence given in the foregoing pages will be able to judge how far such statements go towards meeting it. ${ }^{1}$

1 In a foot-note on the same page (227) another passage is adduced from od. 6. $50 \mathrm{ff}$., where it is said that Nausicaa, after finding her mother at the hearth, met with $(\xi \dot{v} \mu \beta \lambda \eta \tau o)$ her father as he was going forth to the council. This argument assumes that the hearth at which Nausicaa found her mother was in the women's apartinents, and that, as Nausicaa, coming thence, 'met' her father leaving the house, she entered the hall by the door from the court. The answer is furnished by $O d$. 7. $139 \mathrm{ff}$. We there find Aretè and Alcinous sitting together in the men's hall near the '́ $\sigma \chi \alpha \dot{\alpha} \rho \alpha$ at its upper end,-where Penelope also sits in 20. 55, and where Helen joins Menelaus (4. 121). Nausicaa, on awaking, wishes to tell her dream to her parents. She goes $\kappa \alpha \tau \grave{\alpha} \delta \dot{\delta} \mu \alpha \tau \alpha$, ' through the house,' from ner own bedchamber in the women's apartments, to the men's hall, - the door between them being open. In the hall she finds her mother. Her father she found, we may suppose, in the prodomos or in the aulè, 'about to go furth.' It 
It has been suggested by Prof. Gardner that, as the remains of the house-walls at Tiryns are only about three feet above the ground, a raised postern (o $\rho \sigma o \theta \dot{v} \rho \boldsymbol{a}$ ) may once have existed in a side-wall of the megaron. On this point, I can only refer to the statement of Dr. Dörpfeld (p. 228), that no trace of such a postern is now discernible. Let us suppose, however, that it once existed. It would then have necessarily been the usual mode of access from the women's apartments to the men's hall. To it, therefore, we should have to refer the often-repeated phrase concerning Penelope standing 'by the door-post of the hall' (1. 333, etc.); which, however, manifestly refers to a principal entrance, and not merely to a postern in a side-wall. But the hypothesis of an ópootí $\rho a$ at Tiryns, even if it were probable in itself, would leave untouched a whole series of irreconcilable discrepancies between the house at Tiryns and the house of the Odyssey. These have been exhibited in the foregoing pages. Here it is enough to recali a few of them in the briefest terms. (1) Odysseus, being at the lower end of the hall, refuses to go to the women's rooms because he would have to pass up the hall among the suitors. (Above, I. 1). At Tiryns he would only have had to turn his back upon the suitors, and to leave the hall. (2) The women, coming from their own sleepingrooms at night, issue from the men's hall, and pass by Odysseus sleeping in the prodomos. At Tiryns they would have gone out by the separate approach to their own court. They could not have passed through the men's hall or its prodomos. (Above, I. 2). (3) Eumaeus, when at the upper end of the hall, is in the right position to call Eurycleia forth from the women's apartments, and to charge her privily to close them. (Above, II. 1). At Tiryns, - even with the hypothetical ó $\rho \sigma o \theta \dot{v} \rho a$,this could not have so happened. (4) After the slaying, Telemachus, being in the men's hall, calls forth Eurycleia by

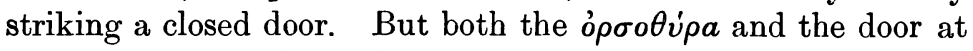
the lower end of the hall were then open. And the men's hall

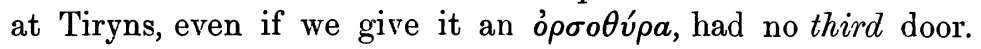
(5) The armoury at Tiryns has to be identified with one of the small rooms on the side of the women's hall furthest from the

is absurd to press $\xi u ́ \mu \beta \lambda \eta \tau o$ as if it necessarily implied that the two persons were moving in exactly contrary directions. It means simply 'fell in with,' 'chanced to find.' 
men's hall. Such a position-accessible from the men's hall only by long and intricate routes -is utterly incompatible with the swift and easy access to the armoury which is supposed in book xxii.

As Prof. Gardner has well observed in this Journal,1 'the best proof that the Homeric house had historical reality is to be found in the fact that in the Greek mansion of historical times we can see the descendant of the house of Homer.' That is, as he there explains, the later $a^{\nu} \nu \delta \rho \omega \dot{\nu}$ answers to the Homeric

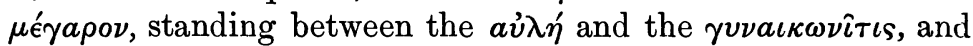
communicating with both. This form of house was suited to the Hellenic spirit in domestic life, which was intermediate between the oriental and the modern European; providing, on the one hand, for the seclusion of women from the outer world, and, on the other, for the social unity of the family. The difference between this Hellenic form of house and the form said to exist at Tiryns is not merely a variation of detail; in regard to the most vital aspect of the home, it is a contrast of type. And if the Tiryns type is assumed as that which the Homeric poet intended, the Odyssey ceases to be intelligible.

R. C. JEBB.

1 Vol. iii. p. 281. 